\title{
Phytochemical analysis and biological activities of ethanolic extract of Curcuma longa rhizome
}

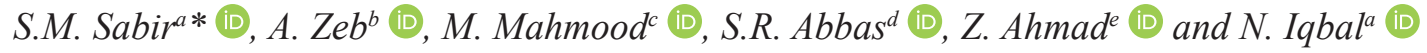 \\ aUniversity of Poonch, Department of Chemistry, Rawalakot, Azad Kashmir, Pakistan \\ ${ }^{b}$ University of Malakand, Department of Biochemistry, Chakdara, Pakistan \\ 'University of Poonch, Department of Zoology, Rawalakot Azad Kashmir, Pakistan \\ ${ }^{\mathrm{d}}$ Karakoram International University, Hunza Campus, Department of Biological Sciences, Gigit, Pakistan \\ ${ }^{\mathrm{e}}$ The Islamia University Bahawalpur, University College of Agriculture and Environmental Sciences, Department of Food \\ Science and Technology, Bahawalpur, Pakistan \\ *e-mail: drmubashar@upr.edu.pk
}

Received: November 1, 2019 - Accepted: February 26, 2020 - Distributed: August 31, 2021

(With 3 Figures)

\begin{abstract}
Curcuma longa is an important dietary plant which possess several pharmacological activities, including antioxidant, antimicrobial, anti-inflamatory, anticancer and anti clotting etc. The aim of the present study was to determine the phenolic profile of Curcuma longa and in vitro antioxidant and antidiabetic activities. In HPLC chromatogram of Curcuma longa rhizome extract 15 phenolic compounds were identified namely Digalloyl-hexoside, Caffeic acid hexoside, Curdione, Coumaric, Caffeic acid, Sinapic acid, Qurecetin-3-D-galactoside, Casuarinin, Bisdemethoxycurcumin, Curcuminol, Demethoxycurcumin, and Isorhamnetin, Valoneic acid bilactone, Curcumin, Curcumin- $O$-glucuronide respectively. The ethanolic extract displayed an $\mathrm{IC}_{50}$ value of $37.1 \pm 0.3 \mu \mathrm{g} / \mathrm{ml}$ against alpha glucosidase. The $\mathrm{IC}_{50}$ value of DPPH radical scavenging activity was $27.2 \pm 1.1 \mu \mathrm{g} / \mathrm{mL}$. It is concluded that ethanolic extract of Curcuma long is rich source of curcumin and contain several important phenolics. The in vitro antioxidant and alpha glucosidase inhibitory effect of the plant justifies its popular use in traditional medicine.
\end{abstract}

Key words: Curcuma longa, HPLC analysis, Curcuminoid, DPPH activity, alpha glucosidase inhibitory activity.

\section{Análise fitoquímica e atividades biológicas do extrato etanólico do rizoma de Curcuma longa}

\section{Resumo}

A Curcuma longa é uma importante planta presente na dieta da população, pois possui diversas atividades farmacológicas, incluindo antioxidante, antimicrobiana, anti-inflamatória, anticancerígena, anticoagulante etc. O objetivo do presente estudo foi elucidar o perfil fenólico da Curcuma longa e determinar as atividades antioxidante e antidiabética in vitro do extrato. No cromatograma por HPLC do extrato de rizoma de Curcuma longa, foram identificados 15 compostos fenólicos: digaloilhexosídeo, hexosídeo de ácido cafeico, curdiona, cumárico, ácido cafeico, ácido sinápico, quercetina-3-D-galactosídeo, casuarinina, bisdemetoxicurcumina, curcuminol, demetoxicurcumina, isoramnetina, bilactona de ácido valônico, curcumina e curcumina-O-glicuronídeo. O extrato etanólico apresentou um valor de IC50 de 37,1 $\pm 0,3 \mu \mathrm{g} / \mathrm{mL}$ em relação à alfaglucosidase. O valor de IC50 da atividade de eliminação de radicais DPPH foi de 27,2 $\pm 1,1 \mu \mathrm{g} / \mathrm{mL}$. Conclui-se que o extrato etanólico de Curcuma longa é uma rica fonte de curcumina e contém várias substâncias fenólicas importantes. $\mathrm{O}$ efeito antioxidante in vitro e inibidor da alfa-glucosidase da planta justifica seu uso popular na medicina tradicional.

Palavras-chave: Curcuma longa, análise por HPLC, Curcuminoide, atividade DPPH, atividade inibidora de alfa-glucosidase.

\section{Introduction}

Diabetes mellitus (DM) is the disorder with servere micro and macro complication that results in significant deaths. It is main causes of death in the world. There are limited effective therapies to cure diabetes. The use of insulin and other antidiabetic agents cause unpleasant side effects, thus there is need to find safe natural products to treat diabetes. Long term complications such as organs failure are the result of chronic hyperglycemia of diabetes (Olatunde et al., 2014). DM also represented by lipidaemia and oxidative stress (Ghazanfar et al., 2014). Although many traditional medicinal plants are effective in decreasing blood sugar, most of these are not practically utilized in severe 
diabetes (Ranilla et al., 2010). Many plants have shown biological activities and utilized as standardized extracts (Dar et al., 2019; Silva et al., 2019; Pontes et al., 2019).

Turmeric (Curcuma longa) is a common plant which belongs to family Zingberaceae (Thomas-Eapen, 2009). The rhizome of the plant are dried, ground and boiled to get yellow powder which is used as food color in curry powder in Asian Countries (Goel et al., 2008). Turmeric powder is a food preservative due to its antioxidant action and adds to the flavor and fragrance of food (E1 Demerdash et al., 2012; Aggarwal et al., 2007). Turmeric contains curcumin, demethoxycurcumin, bisdemethoxycurcumin and rich in volatile oil (Shehzad et al., 2013). Curcuma longa possess several pharmacological activities, including antioxidant, antimicrobial, anti-inflamatory, anticancer, anti clotting etc. (Akbik et al., 2014; Aggarwal and Harikumar, 2009; Widowati et al., 2018). The phenolic composition of Cucuma longa has not been studied in detail. The present study was therefore, aimed to evaluate the phenolic composition of ethanol extract of Curcuma longa. The antioxidant and antidiabetic activities of Curcuma longa were also determined.

\section{Materials and Methods}

\subsection{Plant extract}

Rhizome of the plant was collected locally, identified by a botanist and a voucher specimen was submitted at the Herbarium of the University of Poonch, Department of Botany (Ref. No. BOT/2018/35).

Finely grounded rhizome (25g) was soaked for 3 days in ethanol $(500 \mathrm{ml})$ with constant stirring and filtered with the help of filter paper. The extraction procedure was repeated three times and the filtrates were pooled. The filtrate was evaporated by rotary evaporator $\left(45^{\circ} \mathrm{C}\right)$ producing $3.5 \mathrm{~g}(14 \% \mathrm{w} / \mathrm{w})$ extract.

\subsection{HPLC analysis of phenolic compounds}

The dried ethnaol extract of Curcuma longa was dissolved in ethanol $(1 \mathrm{mg} / \mathrm{mL})$, filtered and subjected for analysis by Shimadzu HPLC system as reported by Zeb (2015). The best separation was achieved in $40 \mathrm{~min}$ using gradient elution of methanol, deionized water and acetic acid on a Zorbax plus C18 column $(4.6 \times 100 \mathrm{~mm}$, $3.5 \mu \mathrm{m})$ at $25^{\circ} \mathrm{C}$. The chromatography peaks were confirmed by comparing its retention time with those of reference standards and by DAD spectra $(200-500 \mathrm{~nm})$.

\subsection{Determination of alpha glucosidase inhibitory activity of extract}

Alpha glucosidase inhibitory activity was determined by the method described by Sancheti et al., (2011)

\subsection{DPPH radical scavenging activity of extract}

Scavenging of the DPPH radical (ethanolic solution of $0.25 \mathrm{mM}$ ) was assayed in vitro (Hatano et al., 1988). The results were expressed as percent inhibition calculated from the control.

\subsection{Statistical analysis}

The results were expressed as mean \pm standard deviation. The data was analyzed by ONE WAY ANNOVA followed by Duncan multiple range test (DMRT) where necessary. Satista 7.1 was used as software package.

\section{Results and Discussion}

In HPLC chromatogram of Curcuma longa rhizome extract the peak of Digalloyl-hexoside appeared at retention time of 1 min (peak 1), Caffeic acid hexoside at $8.6 \mathrm{~min}$ (peak 2), Curdione at 10.3 min (peak 3), Coumaric acid at $13.1 \mathrm{~min}$ (peak 4), Caffeic acid at $14.1 \mathrm{~min}$ (peak 5), Sinapic acid at $15.9 \mathrm{~min}$ (peak 6), Qurecetin-3-D-galactoside at $23.6 \mathrm{~min}$ (peak 7), Casuarinin at $25.2 \mathrm{~min}$ (peak 8), Bisdemethoxycurcumin at 26.1 (peak 9), Curcuminol at $26.7 \mathrm{~min}$ (peak 10), Demethoxycurcumin at $29.6 \mathrm{~min}$ (peak 11) and Isorhamnetin at $30.1 \mathrm{~min}$ (peak 12), Valoneic acid bilactone at $31 \mathrm{~min}$ (peak 13), Curcumin at $35 \mathrm{~min}$ (peak 14), curcumin-O-glucuronide at $37.2 \mathrm{~min}$ (peak 15) respectively (Figure 1 and Table 1). Plants are rich in phenolic compounds which stabilize the free radicals by inhibiting lipid peroxidation (Newairy and Abdou, 2009; Juang et al., 2004). The pure curcumin was detected at $t_{R}$ of $35 \mathrm{~min}$ with a concentration of $3202.9 \mu \mathrm{g} / \mathrm{g}$ in dry ethanolic extract of rhizome. Demethoxycurcumin concentration was noted to be $2313.9 \mu \mathrm{g} / \mathrm{g}$ while, Bisdemethoxycurcumin amount was found to $250.1 \mu \mathrm{g} / \mathrm{g}$. The previous studies have shown the presence of three compounds, namely curcumin $(60-80 \%)$, demethoxycurcumin $(15-30 \%)$ and bisdesmethoxycurcumin (2-6\%) (Ravindranath and Satyanarayana, 1980, Satyavati et al., 1976).

The inhibition of alpha glucosidase activity was observed at a concentration range of $10-250 \mu \mathrm{g} / \mathrm{ml}$ and

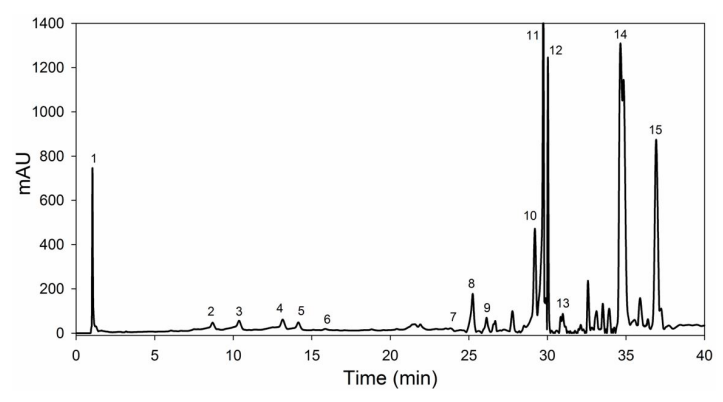

Figure 1. Representative high performance liquid chromatography profile of Curcuma longa rhizome. Digalloyl-hexoside appeared at retention time of $1 \mathrm{~min}$ (peak 1), Caffeic acid hexoside at $8.6 \mathrm{~min}$ (peak 2), Curdione at $10.3 \mathrm{~min}$ (peak 3), Coumaric acid at $13.1 \mathrm{~min}$ (peak 4), Caffeic acid at $14.1 \mathrm{~min}$ (peak 5), Sinapic acid at $15.9 \mathrm{~min}$ (peak 6), Qurecetin-3-D-galactoside at $23.6 \mathrm{~min}$ (peak 7), Casuarinin at 25.2 min (peak 8), Bisdemethoxycurcumin at 26.1 (peak 9), Curcuminol at 26.7 min (peak 10), Demethoxycurcumin at $29.6 \mathrm{~min}$ (peak 11) and Isorhamnetin at $30.1 \mathrm{~min}$ (peak 12), Valoneic acid bilactone at $31 \mathrm{~min}$ (peak 13), Curcumin at $35 \mathrm{~min}$ (peak 14), curcumin- $O$ glucuronide at $37.2 \mathrm{~min}$ (peak 15). 
Table 1. Identification and quantification of phenolic compounds in Curcuma longa

\begin{tabular}{cclcc}
\hline Peak & Rt & \multicolumn{1}{c}{ Identity } & Absorption spectra & Concentration $(\boldsymbol{\mu g} / \mathbf{g})$ \\
\hline 1 & 1 & Digalloyl-hexoside & 364,235 & $392.3 \pm 5.6$ \\
2 & 8.6 & Caffeic acid hexoside & 283,232 & $157.4 \pm 4.1$ \\
3 & 10.3 & Curdione & 303,280 & $213.3 \pm 3.9$ \\
4 & 13.1 & Coumaric acid & $310,290 \mathrm{sh}, 228$ & $126.6 \pm 8.5$ \\
5 & 14.1 & Caffeic acid & $323,296 \mathrm{sh}, 228$ & $64.0 \pm 4.4$ \\
6 & 15.9 & Sinapic acid & $323,288,228$ & $13.7 \pm 2.1$ \\
7 & 23.6 & Qurecetin-3-D-galactoside & 356,256 & $9.8 \pm 1.8$ \\
8 & 25.2 & Casuarinin & 367,266 & $591.9 \pm 6.5$ \\
9 & 26.1 & Bisdemethoxycurcumin & 418,250 & $250.1 \pm 7.3$ \\
10 & 26.7 & Curcuminol & 426,284 & $180.6 \pm 2.7$ \\
11 & 29.6 & Demethoxycurcumin & 420,280 & $2,313.9 \pm 12.6$ \\
12 & 30.1 & Isorhamnetin & 374,250 & $1,767.7 \pm 14.5$ \\
13 & 31 & Valoneic acid bilactone & 373,265 & $1,081.9 \pm 9.7$ \\
14 & 35 & Curcumin & 428,264 & $3,202.9 \pm 24.5$ \\
15 & 37.2 & curcumin- $O$-glucuronide & 426,270 & $2,151.6 \pm 12.1$ \\
\hline
\end{tabular}

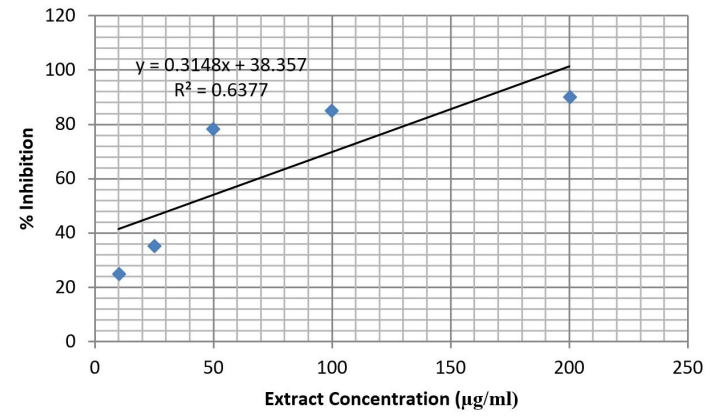

Figure 2. Glucosidase inhibitory activity by ethanolic extract of Curcuma longa. Values are means $\pm \mathrm{SD}(\mathrm{n}=3)$. Values in figures which share different letters are significantly $(p<0.05)$ different from each other by DMRT.

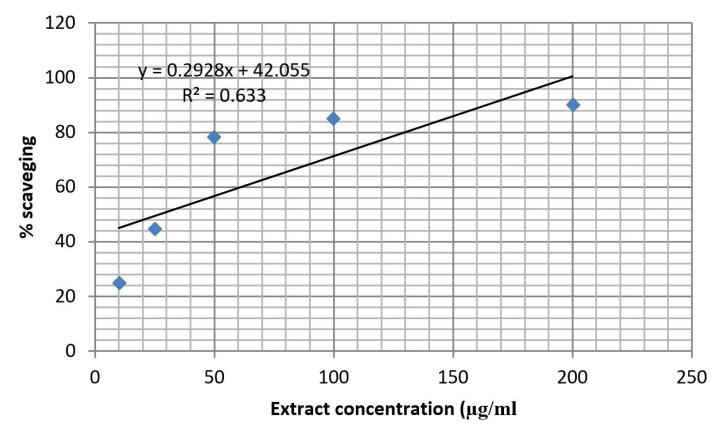

Figure 3. DPPH radical scavenging activity of ethanolic extract obtained from rhizome of Curcuma longa. Values are means $\pm \mathrm{SD}(\mathrm{n}=3)$. Values in figures which share different letters are significantly $(p<0.05)$ different from each other by DMRT.

increased with increasing concentration of extract which indicates that extract possess in vitro antidiabetic activity (Figure 2). The $\mathrm{IC}_{50}$ for inhibition of alpha glucosidase was $37.1 \pm 0.3 \mu \mathrm{g} / \mathrm{ml}$ for ethanolic extract obtained from rhizome.
Blood glucose is elevated when carbohydrate rich diet is consumed as the complex carbohydrate is rapidly absorbed in human intestine due to action $\alpha$-glucosidase enzyme which breaks disaccharides into absorbable monosaccharides. The inhibitors of $\alpha$-glucosidase inhibits the digestion of disaccharides and enable overall smooth glucose profile (Casirola and Ferraris, 2006). The natural products have great diversity in their structure and are potential inhibitor of alpha glucosidase. The phenolic rich ethanolic extract of Curcuma longa has higher potential to inhibit alpha glucosidase and thus can be effectively utilized in diabetes.

The antioxidant activity of the extract was tested by widely used DPPH method. The ethanolic solution of DPPH free radical is reduced on treatment with antioxidants present in the extract. In the DPPH assay, Curcuma longa showed excellent scavenging against the radical (Figure 3). The activity was the highest at maximum concentration, with an $\mathrm{IC}_{50}$ value of $27.2 \pm 1.1 \mu \mathrm{g} / \mathrm{mL}\left(r^{2}=0.96\right)$. The pure gallic acid showed an $\mathrm{IC}_{50}$ value of $3.1 \pm 0.7 \mu \mathrm{g} / \mathrm{mL}$ $\left(r^{2}=0.99\right)$. Antioxidants act at different stages (prevention, interception, and repair) and by different mechanisms as reducing agents by donating hydrogen, by quenching of singlet oxygen, and by acting as chelators and trapping free radicals (Devasagayam et al., 2004). The high DPPH radical scavenging activity of Curcuma longa suggests use against diseases arising from free radical attack.

\section{Conclusions}

The results showed that Curcuma longa rhizome can be considered as potential source of substances with anti-oxidant and anti-diabetic activities. The findings suggest research continuity with the fractions of the crude extract in oxidative stress and other degenerative diseases. These results clearly demonstrated that Curcuma longa has the potential to be selected as an alternative medicinal and food plant that can be utilized in health food products, functional tea and pharmaceutical products. 


\section{Acknowledgement}

We are thankful to Dr. Alam Zeb for providing HPLC facilities.

\section{References}

AGGARWAL, B.B., SUNDARAM, C., MALANI, N. and ICHIKAWA, H., 2007. Curcumin: the Indian solid gold. Advances in Experimental Medicine and Biology, vol. 595, pp. 1-75. http:// dx.doi.org/10.1007/978-0-387-46401-5_1. PMid:17569205.

AGGARWAL, B.B. and HARIKUMAR, K.B., 2009. Potential therapeutic effects of curcumin, the anti-inflammatory agent, against neurodegenerative, cardiovascular, pulmonary, metabolic, autoimmune and neoplastic diseases. The International Journal of Biochemistry \& Cell Biology, vol. 41, no. 1, pp. 40-59. http:// dx.doi.org/10.1016/j.biocel.2008.06.010. PMid:18662800.

AKBIK, D., GHADIRI, M., CHRZANOWSKI, W. and ROHANIZADEH, R., 2014. Curcumin as a wound healing agent. Life Sciences, vol. 116, no. 1, pp. 1-7. http://dx.doi.org/10.1016/j. lfs.2014.08.016. PMid:25200875.

CASIROLA, D.M. and FERRARIS, R.P., 2006. Alpha-glucosidase inhibitors prevent diet - induced increases in intestinal sugar transport in diabetic mice. Metabolism: Clinical and Experimental, vol. 55, no. 6, pp. 832-884. http://dx.doi.org/10.1016/j.metabol.2006.02.011. PMid:16713445.

DAR, K.K., ALI, S., EJAZ, M., NASREEN, S., ASHRAF, N., GILLANI, S.F., SHAFI, N., SAFEER, S., KHAN, M.A., ANDLEEB, S. and MUGHAL, T.A., 2019. In vivo induction of hepatocellular carcinoma by diethylnitrosoamine and pharmacological intervention in Balb C mice using Bergenia ciliata extracts. Brazilian Journal of Biology $=$ Revista Brasileira de Biologia, vol. 79, no. 4, pp. 629638. http://dx.doi.org/10.1590/1519-6984.186565. PMid:31017181.

DEVASAGAYAM, T.P.A., TILAK, J.C., BOLOOR, K.K., SANE, K.S., GHASKADBI, S.S. and LELE, R.D., 2004. Free radicals and antioxidants in human health: current status and future prospects. The Journal of the Association of Physicians of India, vol. 52, pp. 794-804. PMid:15909857.

EL DEMERDASH, A., DAWIDAR, A.M., KESHK, E.M. and ABDEL-MOGIB, M., 2012. Gingerdione from the rhizomes of Curcuma longa. Chemistry of Natural Compounds, vol. 48, no. 4, pp. 646-648. http://dx.doi.org/10.1007/s10600-012-0333-y.

GHAZANFAR, K., GANAI, B.A., AKBAR, S., MUBASHIR, K., DAR, S.A., DAR, M.Y. and TANTRY, M.A., 2014. Antidiabetic Activity of Artemisia amygdalina Decne in Streptozotocin Induced Diabetic Rats. BioMed Research International, vol. 2014, pp. 185676. http://dx.doi.org/10.1155/2014/185676. PMid:24967338.

GOEL, A., KUNNUMAKKARA, A.B. and AGGARWAL, B.B., 2008. Curcumin as "Curecumin": from kitchen to clinic. Biochemical Pharmacology, vol. 75, no. 4, pp. 787-809. http:// dx.doi.org/10.1016/j.bcp.2007.08.016. PMid:17900536.

HATANO, T., KAGAWA, H., YASUHARA, T. and OKUDA, T., 1988. Two new flavonoids and other constituents in licorice root; their relative astringency and radical scavenging effects. Chemical \& Pharmaceutical Bulletin, vol. 36, no. 6, pp. 2090-2097. http:// dx.doi.org/10.1248/cpb.36.2090. PMid:3240445.

JUANG, L.J., SHEU, S.J. and LIN, T.C., 2004. Determination of hydrolyzable tannins in the fruit of Sarcococca saligna by high-performance and capillary electrophoresis. Journal of
Separation Science, vol. 27, pp. 718-724. http://dx.doi.org/10.1002/ jssc.200401741. PMid:15387468.

NEWAIRY, A.S. andABDOU, H.M., 2009. Protective role of flax lignans against lead acetate-induced oxidative damage and hyperlipidemia in rats. Food and Chemical Toxicology, vol. 47, no. 4, pp. 813-818. http://dx.doi.org/10.1016/j.fct.2009.01.012. PMid:19271316.

OLATUNDE, A., JOEL, E.B., TIJJANI, H., OBIDOLA, S.M. and LUKA, C.D., 2014. Antidiabetic Activity of aquoeous extract of curcuma longa (Linn) rhizome in normal and alloxan induced diabetic rats. Researcher, vol. 6, pp. 58-65.

PONTES, F.C.,ABDALLA, V.C.P., IMATOMI, M., FUENTES, L.F.G. and GUALTIERI, S.C.J., 2019. Antifungal and antioxidant activities of mature leaves of Myrcia splendens (Sw.) DC. Brazilian Journal of Biology = Revista Brasileira de Biologia, vol. 79, no. 1, pp. 127132. http://dx.doi.org/10.1590/1519-6984.179829. PMid:29742197.

RANILLA, L.G., KWON, Y.I., APOSTOLIDIS, E. and SHETTY, K., 2010. Phenolic compounds, antioxidant activity and in vitro inhibitory potential against key enzymes relevant for hyperglycemia and hypertension of commonly used medicinal plants, herbs and spices in Latin America. Bioresource Technology, vol. 101, no. 12, pp. 4676-4689. http://dx.doi. org/10.1016/j.biortech.2010.01.093. PMid:20185303.

RAVINDRANATH, V. and SATYANARAYANA, M.N., 1980. An unsymmetrical diarylheptanoid from Curcuma longa. Phytochemistry, vol. 19, no. 9, pp. 2031-2032. http://dx.doi. org/10.1016/0031-9422(80)83033-0.

SHEHZAD, A., REHMAN, G. and LEE, Y.S., 2013. Curcumin in inflammatory diseases. BioFactors (Oxford, England), vol. 39, no. 1, pp. 69-77. http://dx.doi.org/10.1002/biof.1066. PMid:23281076.

SANCHETI, S., SANCHETI, S., LEE, S.H., LEE, J.E. and SEO, S.Y., 2011. Screening of Korean medicinal plant extracts for $\alpha$-glucosidase inhibitory activities. Iranian Journal of Pharmaceutical Research, vol. 10, no. 2, pp. 261-264. PMid:24250352.

SILVA, F.R.G., MATIASA, T.M.S., SOUZA, L.I.O., MATOSROCHA, T.J., FONSECA, S.A., MOUSINHOA, K.C. and SANTOS, A.F., 2019. Phytochemical screening and in vitro antibacterial, antifungal, antioxidant and antitumor activities of the red propolis Alagoas. Brazilian Journal of Biology $=$ Revista Brasileira de Biologia, vol. 79, no. 3, pp. 452-459. http://dx.doi. org/10.1590/1519-6984.182959. PMid:30379200.

SATYAVATI, G.V., RAINA, M.R. and SHARMA, M., 1976. Medicinal plants of India. New Delhi: Indian Council of Medical Research.

THOMAS-EAPEN, N.E., 2009. Turmeric: the intriguing yellow spice with medicinal properties. Explore, vol. 5, no. 2, pp. 114-115. http://dx.doi.org/10.1016/j.explore.2008.12.008. PMid:19272583.

WIDOWATI, W., WARGASETIA, T.L., AFIFAH, E., MOZEF, T., KUSUMA, H.S.W., NUFUS, H., ARUMWARDANA, S., AMALIA, A. and RIZAL, R., 2018. Antioxidant and antidiabetic potential of Curcuma longa and its compounds. Asian Journal of Agriculture and Biology, vol. 6, pp. 149-161.

ZEB,A., 2015.A reversed phase HPLC-DAD method for the determination of phenolic compounds in plant leaves. Analytical Methods, vol. 7, no. 18, pp. 7753-7757. http://dx.doi.org/10.1039/C5AY01402F. 